\title{
Immunological manipulation of adiposity
}

\author{
BY D A VID J. FLINT \\ Hannah Research Institute, Ayr KA6 5HL
}

The deposition of excess energy in the form of triacylglycerol in adipose tissue has become an undesirable trait both in animals and in man. Indeed, it has been the increasingly sedentary lifestyle of man, with the consequential increase in fat accumulation in humans, which ultimately has been the driving force to reduce fat content in domestic species. Since most meats are perceived, rightly or wrongly, as high-fat foods and since saturated animal fats are considered to be the poor relation of their polyunsaturated counterparts found predominantly in vegetable foodstuffs there has been a steady downward trend in the consumption of many meat and dairy products.

In attempting to address this problem endocrinologists enjoyed a 'head-start' since both growth hormone (GH; see Vernon \& Flint, 1989) and $\beta$-adrenergic agonists (see Hanrahan et al. 1986) have long been known to have favourable effects on body composition, increasing lean body mass and decreasing body fat. Certain $\beta$-adrenergic agonists behave not only as classical lipolytic agents but also with apparently direct effects on muscle accretion (Bergen et al. 1987; Eadara et al. 1987; Maltin et al. 1987; Yang \& McElligott, 1989) whilst GH increases body nitrogen retention, antagonizes the actions of insulin (see Vernon \& Flint, 1989) and enhances responsiveness to $\beta$-adrenergic compounds (Vernon et al. 1987). Despite these favourable effects and despite their ready availability (in recombinant DNA form for bovine and porcine $\mathrm{GH}$ ) neither of these classes of compounds is licensed for such use in major developed countries. There is genuine concern over the use of $\beta$-adrenergic compounds because of problems of short withdrawal periods and possible adverse effects on meat quality (Warris \& Kestin, 1988; Warris et al. 1989, 1990), whilst the inability to successfully license bovine GH for use in animal production systems continues despite the fact that it must now be the most exhaustively researched (and certainly documented) compound still seeking approval for use and despite the fact that its human counterpart is available for direct injection into humans.

The desire to use non-hormonal approaches, with long withdrawal periods from treatment, led to the search for immunization techniques which could induce similar effects. Not surprisingly these approaches have in the main focused on attempts to manipulate endogenous $\mathrm{GH}$ action. The approaches can be broadly defined as immunoneutralization, immuno-enhancement, immuno-mimicry and immunocytotoxicity.

\section{IMMUNONEUTRALIZATION}

The use of antibodies in a classical sense, to bind to and neutralize agents in blood was first attempted, in terms of animal growth, by immunization against somatostatin. This hormone is secreted from the hypothalamus and acts on the pituitary gland to inhibit GH secretion. Thus, by blocking somatostatin action, GH secretion should be increased. Early results in non-improved breeds of sheep were very encouraging (Spencer et al. 
Table 1. Effects of growth hormone $(G H)$ deficiency induced with antiserum to rat $G H$ $(r G H)$ on body-weight and fat deposition at 8 weeks of age $\dagger$

(Mean values with their standard errors)

\begin{tabular}{|c|c|c|c|c|c|c|c|}
\hline & & & \multicolumn{5}{|c|}{ Adipocyte cell number $\left(\times 10^{-6}\right)$} \\
\hline & \multicolumn{2}{|c|}{ Body-wt (g) } & \multicolumn{2}{|c|}{ Parametrial (A) } & \multicolumn{2}{|c|}{ Subcutaneous (B) } & \multirow[b]{2}{*}{$\mathrm{B} / \mathrm{A}$} \\
\hline & Mean & SE & Mean & $\mathrm{SE}$ & Mean & SE & \\
\hline Control & 188 & 4 & 21 & 2 & 23 & 3 & $1 \cdot 1$ \\
\hline Anti-rGH: Short term $\ddagger$ & $145^{* *}$ & 6 & 17 & 2 & $49 * *$ & 6 & $2 \cdot 9$ \\
\hline Long term§ & $83^{* *}$ & 3 & $6^{* *}$ & 1 & $14^{*}$ & 2 & $2 \cdot 3$ \\
\hline
\end{tabular}

Mean values were significantly different from control values: ${ }^{*} P<0 \cdot 05,{ }^{*} P<0 \cdot 01$.

$\uparrow$ Neutralization of $\mathrm{GH}$ produced a graded decrease in body-weight, and in parametrial cell numbers. By contrast short-term anti-rGH caused a doubling of adipocyte numbers in subcutaneous fat and a much less marked decrease in subcutaneous adipocytes after long-term treatment. This led to an increase in the value for subcutaneous:parametrial adipocytes from approximately 1 up to $2-3$.

$\$$ Anti-rGH administered from $2-25 \mathrm{~d}$ of age.

$\S$ Anti-rGH administered from 2-56 d of age.

$1983 a, b)$, but subsequent studies in a number of different species have provided mixed results (see e.g. Trout \& Schanbacher, 1990). Despite this fact the approach continues to interest research groups to this very day. One of the surprising elements of this approach was that even when immunization against somatostatin produced improved growth rates it never achieved the reduction in fat content so characteristic of exogenous treatment with GH (Etherton et al. 1987; Pell \& Bates, 1991).

These surprising findings may be explained in part by the dual characteristics of $\mathrm{GH}$ action in adipose tissue since, although $\mathrm{GH}$ enhances net mobilization of triacylglycerol from mature adipocytes, paradoxically it appears to stimulate the differentiation of pre-adipocytes in vitro (see Vernon \& Flint, 1989). We have recently shown that this latter effect is evident in vivo, since in rats treated neonatally with an antiserum to $\mathrm{GH}$, adipocyte differentiation in internal fat depots is dramatically decreased (Table 1). Surprisingly, however, subcutaneous fat appeared almost totally insensitive to the absence of $\mathrm{GH}$ early in life, with sensitivity to $\mathrm{GH}$ possibly also varying in this depot depending on age. It is, thus, feasible that neutralization of $\mathrm{GH}$ action at critical time-points may be successfully used not just to manipulate total body fat but possibly to induce site-specific effects on adipose tissue.

An alternative strategy which might favour reduced fat deposition involves immunoneutralization of insulin. Direct immunization has, however, proved to be extremely difficult since the pancreas has a considerable capacity to secrete large amounts of insulin until there is sufficient free hormone to elicit biological effects such as maintaining normoglycaemia. An alternative strategy could, however, involve immunoneutralization of gastrointestinal hormones such as gastric inhibitory polypeptide (GIP) which augment insulin secretion, have direct lipogenic effects on adipose tissue and which have been implicated as possible mediators of certain obese syndromes (Ebert \& Creutzfeldt, 1987). Even in ruminant species where very little glucose is absorbed from the diet both GIP and glucagon-like peptide-1 appear to have important roles to play in lipid metabolism (Faulkner \& Pollock, 1991; McCarthy et al. 1992). Since 
GIP is secreted in response to dietary triacylglycerol and has direct effects on lipogenesis in adipose tissue (Beck, 1989) neutralization of its actions should prove advantageous in reducing adipose mass. Although immunization against GIP has been shown to reduce insulin responses in rodents (Ebert et al. 1979), no long-term consequences on adipose tissue metabolism have been reported.

\section{IMMUNO-ENHANCEMENT}

As its name implies this particular approach involves the process of enhancing hormone action by means of appropriate interactions with antibodies. Thus, rather than neutralizing the actions of $\mathrm{GH}$, antibodies to $\mathrm{GH}$, particularly monoclonal antibodies, have been shown to enhance the biological activity of GH in GH-deficient mice (Aston et al. 1986). This approach has been developed in several ways. First, the effect has been demonstrated in domestic livestock utilizing several biological responses to GH. For example, antibodies pre-complexed to $\mathrm{GH}$ have been shown to enhance milk production (a $\mathrm{GH}$ response) and the diabetogenic effect of GH (Pell et al. 1989). The ability of monoclonal antibodies administered alone to enhance the actions of endogenous $\mathrm{GH}$ has also been shown (Holder et al. 1985). Second, this response is not restricted to monoclonal antibodies since polyclonal antibodies of 'restricted specificity', i.e. raised against a small part of the amino acid sequence of GH, are also effective (Bomford \& Aston, 1990). Third, these peptide 'enhancing regions' of GH have been used to actively immunize animals in order to induce the production of antibodies which will complex with and enhance the biological activity of GH (Pell et al. 1991).

The precise mechanism of action of such antibodies is still unclear but proposals have included increased half-life, targeting to particular tissues (e.g. liver), interactions with specific subsets of receptors and increased time of receptor occupancy. The fact that $\mathrm{GH}$ conjugated to itself has enhanced bioactivity makes this phenomenon even more perplexing (Holder \& Aston, 1989).

\section{IMMUNO-MIMICRY}

By utilizing the concept of immune networks in which each antibody produced by the body evokes an anti-antibody, Jerne (1974) proposed that a subset of these antiantibodies would bind to the same site on the original antibody as the antigen and thereby serve as a so-called internal image of the antigen. We utilized this approach to produce antibody mimics of rat $\mathrm{GH}$ and showed them to bind specifically to $\mathrm{GH}$ receptors but not prolactin or insulin receptors present in the same tissues. We were further able to show in short-term experiments that such antibodies given to GHdeficient (hypophysectomized) rats could stimulate increased body-weight gain (Gardner et al. 1990). These particular studies were too short, however, to address the question of reduced adipose tissue mass. One of the potential spin-offs of antibody mimics of $\mathrm{GH}$ is the possibility of producing a number of different antibodies which mimic different parts of the GH molecule. Such a group of antibodies would allow us to address the proposal that $\mathrm{GH}$ binds to different subsets of $\mathrm{GH}$ receptors (which elicit different biological actions?) via different binding sites on the GH molecule (Thomas et al. 1987). Although we were able to produce monoclonal antibodies which mimicked GH in terms of binding 
Table 2. Effects of passive immunization with antisera to pig adipocyte membranes on fat and lean content of pigs

(Mean values with their standard errors)

\begin{tabular}{|c|c|c|c|c|c|c|}
\hline & \multirow{2}{*}{\multicolumn{2}{|c|}{$\begin{array}{l}\text { Back-fat thickness } \\
\text { at P2 site }(\mathrm{mm})\end{array}$}} & \multicolumn{4}{|c|}{ Forelimb joint weights (kg) } \\
\hline & & & \multicolumn{2}{|c|}{ Fat } & \multicolumn{2}{|c|}{ Lean } \\
\hline & Mean & $S E$ & Mean & SE & Mean & SE \\
\hline Control & 12.9 & 0.7 & $1 \cdot 01$ & $0 \cdot 10$ & $2 \cdot 00$ & 0.07 \\
\hline Antibody-treated & $9 \cdot 0^{*}$ & 0.7 & $0.76^{*}$ & $0 \cdot 11$ & $2 \cdot 23$ & 0.14 \\
\hline
\end{tabular}

Mean values were significantly different from control values: ${ }^{*} P<0 \cdot 05$.

to GH receptors, they had very low affinities for the receptor and, thus, did not prove suitable for such studies.

Recently two groups have been examining the interactions of human $\mathrm{GH}$ with its receptor utilizing mutagenesis studies (Bass et al. 1991; Cunningham et al. 1991) and X-ray crystallography (de Vos et al. 1992) and have described the precise contact residues involved in this binding interaction. Unexpectedly, their studies revealed that one GH molecule bound to two GH receptors inducing them to dimerize. With knowledge of these interactive sites available to us the prospect of designing antireceptor antibodies which may serve as hormone agonists becomes a distinct possibility.

\section{IMMUNOCYTOTOXICITY}

Probably the most direct approach to reducing body fat deposition is to consider adipose tissue as an invading organism and produce antibodies capable of binding to and destroying adipocytes. We demonstrated the feasibility of this approach in rats with adipocyte destruction evident immediately post-injection and with very slow recovery of lost adipose mass (Flint et al. 1986; Futter \& Flint, 1987; Panton et al. 1990). This adipocyte destruction identifies this approach as conceptually different from virtually all other approaches to reduce body fat (excepting lipectomy) since it aims to remove cells rather than regulate their metabolism. Rather than becoming lighter than their control counterparts, rats treated with antibodies to adipocytes actually became heavier due to increased protein deposition. Reduced fat deposition has also been achieved in rabbits (Dulor et al. 1990) and sheep (Moloney \& Allen, 1989; Nassar \& Hu, 1991), although without increases in lean body mass. We have, however, shown compensatory increases in lean tissue and significant decreases in adipose tissue content of pigs passively immunized at 6 weeks of age (Table 2). Using an active immunization approach in which pigs were injected with pig adipocyte plasma membranes conjugated to ovalbumin we have demonstrated reduced back-fat thickness in pigs, although without compensatory increases in lean body mass (Table 3 ).

\section{SUMMARY}

Although hormonal regulators of adiposity are available they as yet have not been licensed for use. Withdrawal periods and delivery systems are still potential problems in 
Table 3. Active immunization of pigs with pig adipocyte plasma membranes

(Mean values with their standard errors)

\begin{tabular}{|c|c|c|c|c|c|}
\hline \multirow[t]{2}{*}{$n \ldots$} & \multicolumn{2}{|c|}{$\begin{array}{c}\text { Control } \\
19\end{array}$} & \multicolumn{2}{|c|}{$\begin{array}{c}\text { Immunized } \\
9\end{array}$} & \multirow{2}{*}{$\begin{array}{c}\text { Percentage } \\
\text { change }\end{array}$} \\
\hline & Mean & $\mathrm{SE}$ & Mean & SE & \\
\hline Cold carcass wt $(\mathrm{kg})$ & 69.7 & $1 \cdot 0$ & $67 \cdot 2$ & $2 \cdot 7$ & $-3 \cdot 6$ \\
\hline P2 back-fat thickness (mm) & $16 \cdot 5$ & 0.9 & $13 \cdot 4^{*}$ & 0.9 & $-18 \cdot 7$ \\
\hline Leg muscle wt $(\mathrm{kg})$ & 5.9 & $0 \cdot 1$ & $5 \cdot 8$ & $0 \cdot 2$ & $-1 \cdot 7$ \\
\hline Leg subcutaneous fat $(\mathrm{kg})$ & $1 \cdot 52$ & 0.08 & $1 \cdot 37$ & 0.04 & -9.9 \\
\hline
\end{tabular}

Mean value was significantly different from control value: ${ }^{*} P<0 \cdot 05$.

maximizing their effectiveness. Immunization techniques, on the other hand, suffer none of the problems of withdrawal periods or requirement for frequent injection/ implantation. As such they are clearly perceived as safe, economic and should have a positive animal welfare image. They are, however, not without their problems. Active immunization in particular involves an autoimmune response and this is typically difficult to evoke and virtually impossible to regulate. In addition, the fact that antibodies may have immunoneutralizing and immunoenhancing properties may explain the apparently contradictory results obtained in various studies as, for example, in the case of immunization against somatostatin. As our knowledge of immune responsiveness and its control increases, however, the possibilities for immune intervention should increase considerably. We may then be faced with ethical rather than practical limitations as to how far we should manipulate growth and body composition.

\section{REFERENCES}

Aston, R., Holder, A. T., Preece, M. A. \& Ivanyi, J. (1986). Potentiation of the somatogenic and lactogenic activity of human growth hormone with monoclonal antibodies. Journal of Endocrinology 110, 381-388.

Bass, S. H., Mulkerrin, M. G. \& Wells, J. A. (1991). A systematic mutational analysis of hormone-binding determinants in the human growth hormone receptor. Proceedings of the National Academy of Science, USA 88, 4498-4502.

Beck, B. (1989). Gastric inhibitory polypeptide: a gut hormone with anabolic functions. Journal of Molecular Endocrinology 2, 169-174.

Bergen, W. G., Johnson, S. E., Skjaerlund, D. M., Merkel, R. A. \& Anderson, D. B. (1987). The effect of ractopamine on skeletal muscle metabolism in pigs. Federation Proceedings 46, 1021.

Bomford, R. \& Aston, R. (1990). Enhancement of bovine growth hormone activity by antibodies against growth hormone peptides. Journal of Endocrinology 125, 31-38.

Cunningham, B. C., Ultsch, M., de Vos, A. M., Mulkerrin, M. G., Clauser, K. R. \& Wells, J. M. (1991). Dimerization of the extracellular domain of the human growth hormone receptor by a single hormone molecule. Science 254, 821-825.

de Vos, A. M., Ultsch, M. \& Kossiakoff, A. A. (1992). Human growth hormone and extracellular domain of its receptor: crystal structure of the complex. Science $255,306-312$.

Dulor, J. P., Reyne, Y. \& Nougues, J. (1990). In vivo effects of a treatment with antibodies to adipocyte plasma membranes in the rabbit. Reproduction Nutrition Developpement 30, 49-58.

Eadara, J., Dalrymple, R. H., De Lay, R. L., Ricks, C. A. \& Romsos, D. R. (1987). Cimaterol, a novel $\beta$-agonist, selectively stimulates white adipose tissue lipolysis and skeletal muscle lipoprotein lipase activity in rats. Federation Proceedings 46, 1020.

Ebert, R. \& Creutzfeldt, W. (1987). Gastrointestinal peptides and insulin secretion. Diabetes and Metabolism Reviews 3, 1-26. 
Ebert, R., Illmer, K. \& Creutzfeldt, W. (1979). Release of gastric inhibitory polypeptide (GIP) by intraduodenal acidification in rats and humans and abolishment of the incretin effect of acid by GIP-antiserum in rats. Gastroenterology 76, 515-523.

Etherton, T. D., Wiggins, J. P., Evock, C. M., Chung, C. S., Rebhun, J. F., Walton, P. E. \& Steele, N. C. (1987). Stimulation of pig growth performance by porcine growth hormone: determination of the dose-response relationship. Journal of Animal Science 64, 433-443.

Faulkner, A. \& Pollock, H. T. (1991). Effects of truncated glucagon-like peptide-1 on the responses of starved sheep to glucose. Journal of Endocrinology 129, 55-58.

Flint, D. J., Coggrave, H., Futter, C. E., Gardner, M. J. \& Clarke, T. J. (1986). Stimulatory and cytotoxic effects of an antiserum to adipocyte plasma membranes on adipose tissue metabolism in vitro and in vivo. International Journal of Obesity 10, 69-77.

Futter, C. E. \& Flint, D. J. (1987). Long-term reduction in adiposity in rats after passive immunization with antibodies to rat fat cell plasma membranes. In Recent Advances in Obesity Research, pp. 181-185 [E. M. Berry, editor]. London: John Libbey.

Gardner, M. J., Morrison, C. A., Stevenson, L. Q. \& Flint, D. J. (1990). Production of anti-idiotypic antisera to rat $\mathrm{GH}$ antibodies capable of binding to $\mathrm{GH}$ receptors and increasing body weight gain in hypophysectomized rats. Journal of Endocrinology 125, 53-59.

Hanrahan, J. P., Quirke, J. F., Bomann, W., Allen, P., McEwan, J. C., Fitzsimmons, J. M., Kotzain, J. \& Roche, J. F. (1986). $\beta$-Agonists and their effects on growth and carcass quality. In Recent Advances in Animal Nutrition, pp. 125-138 [W. Haresign and D. J. A. Cole, editors]. London: Butterworths.

Holder, A. T. \& Aston, R. (1989). Antigen-antibody complexes that enhance growth. In Biotechnology and Growth Regulation, pp. 167-177 [R. B. Heap, editor]. London: Butterworths.

Holder, A. T., Aston, R., Preece, M. A. \& Ivanyi, J. (1985). Monoclonal antibody-mediated enhancement of growth hormone activity in vivo. Journal of Endocrinology 107, R9-R12.

Jerne, N. K. (1974). Towards a network theory of the immune system. Annals of Immunology, Paris 125c, 373-389.

McCarthy, J. P., Faulkner, A., Martin, P. A. \& Flint, D. J. (1992). Changes in the plasma concentration of gastric inhibitory polypeptide and other metabolites in response to feeding in sheep. Journal of Endocrinology 134, 235-240.

Maltin, C. A., Hay, S. M., Delday, M. I., Smith, F. G., Lobley, G. E. \& Reeds, P. J. (1987). Clenbuterol, a beta agonist, induces growth in innervated and denervated rat soleus muscle via apparently different mechanisms. Bioscience Reports 7, 525-532.

Moloney, A. P. \& Allen, P. (1989). Growth and weights of abdominal and carcass fat in sheep immunized against adipose cell membranes. Proceedings of the Nutrition Society $48,14 \mathrm{~A}$.

Nassar, A. H. \& Hu, C. Y. (1991). Growth and carcass characteristics of lambs passively immunized with antibodies developed against ovine adipocyte plasma membranes. Journal of Animal Science 69, 578-586.

Panton, D., Futter, C., Kestin, S. \& Flint, D. J. (1990). Increased growth and protein deposition in rats treated with antibodies to adipocytes. American Journal of Physiology 258, E985-E989.

Pell, J. M. \& Bates, P. C. (1991). The nutritional regulation of growth hormone action. Nutrition Research Reviews 3, 163-192.

Pell, J. M., Flint, D. J., James, S. \& Aston, R. (1991). Immunomodulation of hormones of the somatotropin axis. In Biotechnology for the Control of Growth and Product Quality in Meat Production, pp. 51-66 [P. Van der Wal, editor]. Wageningen: Pudoc.

Pell, J. M., Johnsson, I. D., Pullar, R. A., Morrell, D. J., Hart, I. C., Holder, A. T. \& Aston, R. (1989). Potentiation of growth hormone activity in sheep using monoclonal antibodies. Journal of Endocrinology 120, R15-R18.

Spencer, G. S. G., Garssen, G. J. \& Hart, I. C. (1983a). A novel approach to growth promotion using autoimmunization against somatostatin. I. Effects on growth and hormone levels in lambs. Livestock Production Science 10, 25-37.

Spencer, G. S. G., Garssen, G. J. \& Hart, I. C. (1983b). A novel approach to growth promotion using autoimmunization against somatostatin. II. Effects on appetite, carcass composition and food utilization in lambs. Livestock Production Science 10, 469-477.

Thomas, H., Green, I. C., Wallis, M. \& Aston, R. (1987). Heterogeneity of growth-hormone receptors detected with monoclonal antibodies to human growth hormone. Biochemical Journal 243, 365-372.

Trout, W. E. \& Schanbacher, B. D. (1990). Growth hormone and insulin-like growth factor-I responses in steers actively immunized against somatostatin or growth hormone-releasing factor. Journal of Endocrinology 125, 123-129. 
Vernon, R. G., Finley, E. \& Flint, D. J. (1987). Role of growth hormone in the adaptions of lipolysis in rat adipocytes during recovery from lactation. Biochemical Journal 242, 931-934.

Vernon, R. G. \& Flint, D. J. (1989). Role of growth hormone in the regulation of adipocyte growth and function. In Biotechnology in Growth Regulation, pp. 55-71 [R. B. Heap, C. G. Prosser and G. E. Lamming, editors]. London: Butterworths.

Warriss, P. D. \& Kestin, S. C. (1988). Beta-agonists improve the carcass but may reduce meat quality in sheep. Animal Production 46, 502.

Warriss, P. D., Kestin, S. C. \& Brown, S. N. (1989). The effect of beta-adrenergic agonists on carcass and meat quality in sheep. Animal Production 48, 385-392.

Warriss, P. D., Kestin, S. C., Rolph, T. P. \& Brown, S. N. (1990). The effects of the beta-adrenergic agonist salbutamol on meat quality in pigs. Journal of Animal Science 68, 128-136.

Yang, Y. T. \& McElligott, M. A. (1989). Multiple actions of $\beta$-adrenergic agonists on skeletal muscle and adipose tissue. Biochemical Journal 261, 1-10. 